\title{
On the Loss of a Friend: A Tribute to Larry $\mathbf{S}$. Jordan
}

\author{
Susan D. McHenry
}

The national Emergency Medical Services community mourns the untimely death of Larry S. Jordan, a true champion of EMS and a dear friend to many across the United States.

Larry served the state of Florida, as its Emergency Medical Services (EMS) Director, from 1983 to 1990 . He provided the energy and, more importantly, the leadership to bring the state's EMS program into sharp focus. The program went from a very limited scope of regulation and certification to a vibrant commitment to development of a comprehensive, coordinated emergency medical services system to serve all of Florida.

During his tenure, the state EMS office was expanded from a staff of approximately 20 to the more than 70 personnel necessary to effectively support key programs, address critical issues, and provide needed services. Among new programs implemented under Larry's leadership were a State Grant Program which provides county grants as well as matching grants for local system improvements and a comprehensive injury control program. He also was instrumental in securing passage of comprehensive Trauma System Legislation for the state.

Larry's EMS contributions were in no way limited to his own state. He was President of the National Association of State EMS Directors (NASEMSD) for 1987 and 1988. During his presidency, he made significant progress in enhancing the liaison memberships between NASEMSD and other professional organizations, strengthening the relationship with the National Association of Governors' Highway Safety Representatives, and crafting agreements between NASEMSD and the National Study Center for Trauma and Emergency Medical Systems. He also worked tirelessly toward gaining the involvement of the Federal Emergency Management Agency (FEMA) in pertinent EMS issues. To further this end, he also spent his annual U.S. Army Reserve active duty on assignment to FEMA, State, and Local Service Programs.

Following his term as President of NASEMSD, he very effectively chaired the Association's Government Affairs Committee. In this capacity, Larry provided critical input on National Trauma Systems Legislation (HR 1602), which subsequently was passed and signed by President Bush on 16 November 1990.

As expressed by a fellow State EMS Director, Barak Wolff, "Larry joined our group of State EMS Directors as a non-EMS person, as a generalist, as a manager with fresh energy and organizational savy. He listened to our deliberations, asked some questions, and rapidly developed a vision that NASEMSD could and should be more than a peer support group. He saw that there were needs within EMS that we were uniquely qualified to fulfill and that we should 'go for it.' He helped empower us to take some risks and make some commitments to each other and to our organizational goals. What is most wonderful is that, in the course of his state and national leadership, Larry became both substantive and passionate about EMS."

Another close colleague characterized Larry as "a person with a lot of dreams and the ability to piece together the people who could make them a reality." He acted on good ideas. His unwavering commitment to EMS and his vision for its future make his passing an especially acute loss to all State EMS Directors and to those involved in EMS across the country.

At the request of Larry's family, a Memorial Fund has been established at the National Association of State EMS Directors. Those wishing to make a contribution in Larry's memory should contact Ellen Hume at the Council of State Governments, P.O. Box 11910, Iron Works Pike, Lexington, KY 40578, or by telephone at (606) 231-1885.

Director, Virginia EMS, Department of Public Health, Richmond, Virginia, USA 


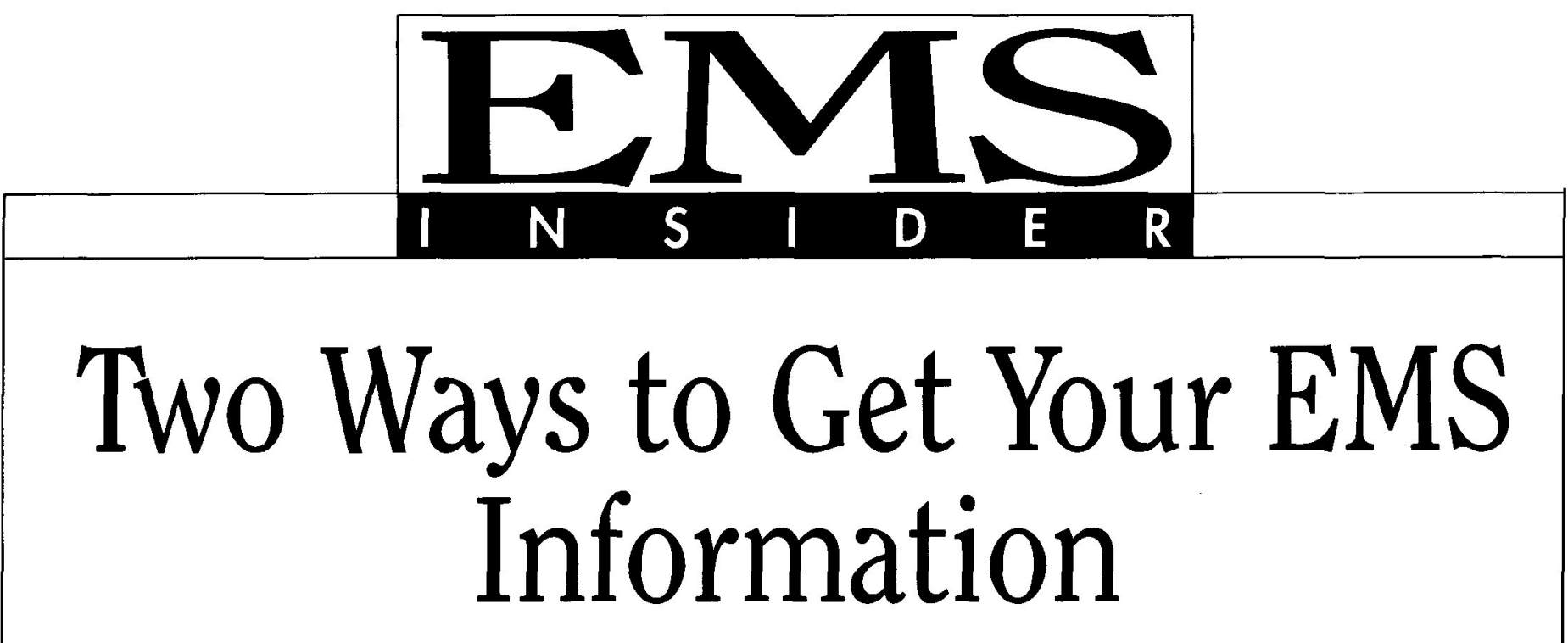

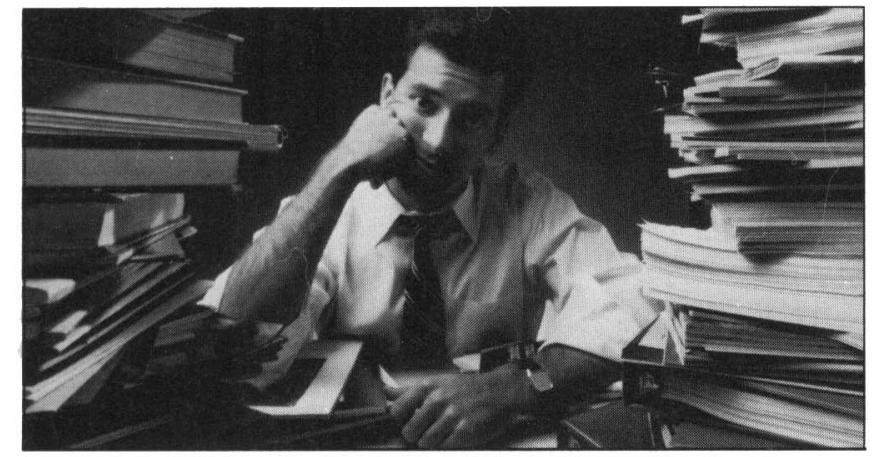

$T_{\text {he oldest and most respected EMS newslet- }}$ ter in the nation-formerly published 1 as the EMS Communicator-the EMS INSIDER has a new look, a new style and a new MONTHLY schedule.

The EMS INSIDER uses 21 st century technology to bring you late-breaking EMS news, weeks, sometimes months, before it is available elsewhere.

The EMS INSIDER covers management issues,

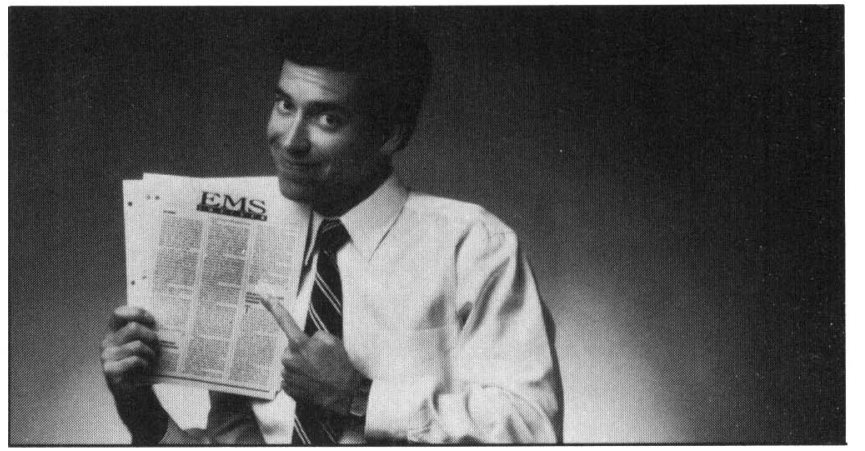

financial topics, new regulations and legislation, controversies and innovations in the field.

For a limited time, Jems Publishing Company is offering the EMS INSIDER at the low price of just $\$ 29.50$ a year $(12$ issues). That's 40 percent off the regular subscription price. Just fill out the coupon below.

There has never been a better time to become an EMS INSIDER.

$\square$ YES, I want to be an EMS INSIDER for only $\$ 29.50$ a year (12 issues)

EMPLOYER/AFFILIATION

[] 1. Hospital

2. Private Ambulance

a 3. Fire Dept./Rescue Squad

4. Third Serv/Mun. Agency

5. Industria//Commercial

6. Other

$$
\text { please specify }
$$

\section{OCCUPATION/POSITION}

A. Physician

B. Nurse/Inst./Coord.

- C. Administrator/Supervisor

D. Paramed/EMT-1/EMT-D

E. EMT (Basic, 1st Resp.)

$\checkmark$ F. Other

please specify

\begin{tabular}{ll}
\hline Print Name & \\
\hline Title & Organization \\
\hline Address & \\
\hline City & State $\quad$ Zip
\end{tabular}

Mail to: ECIC, P.O.Box 1026, Solana Beach, CA 92075

\section{G BILL ME \\ - PAYMENT ENCLOSED \\ - CHARGE MY: \\ 口 VISA D MasterCard \\ Card \#}

Signature

Exp. Date

Canada-please add $\$ 6.00$ per year for postage. Al other foreign-please add $\$ 10.00$ per year surface mail postage; add $\$ 20.00$ per year for air mail postage. Subscriptions must be paid in US. funds. Please allow 6-8 weeks for delivery of first issue. 